Article

\title{
Identification of Entomopathogenic Fungi as Naturally Occurring Enemies of the Invasive Oak Lace Bug, Corythucha arcuata (Say) (Hemiptera: Tingidae)
}

\author{
Marta Kovač ${ }^{1}$, Michał Gorczak ${ }^{2}$ (D), Marta Wrzosek ${ }^{3}$, Cezary Tkaczuk ${ }^{4}$ and Milan Pernek ${ }^{1, *}$ (I) \\ 1 Croatian Forest Research Institute, Division for Forest Protection and Game Management, \\ 10450 Jastrebarsko, Croatia; martam@sumins.hr \\ 2 Institute of Evolutionary Biology, Faculty of Biology, University of Warsaw, 02-096 Warsaw, Poland; \\ gorczak@biol.uw.edu.pl \\ 3 Botanic Garden, Faculty of Biology, University of Warsaw, 02-096 Warsaw, Poland; martawrzosek@gmail.com \\ 4 Institute of Agriculture and Horticulture, Siedlce University of Natural Sciences and Humanities, \\ 08-110 Siedlce, Poland; cezary.tkaczuk@uph.edu.pl \\ * Correspondence: milanp@sumins.hr
}

Received: 16 September 2020; Accepted: 5 October 2020; Published: 7 October 2020

check for updates

Simple Summary: The oak lace bug (OLB), Corythucha arcuata, is a cell sap-sucking insect that is native to North America but has spread rapidly in European countries as an invasive pest. The main hosts are oaks, but it can develop on other forest species as well. Its occurrence is worrying in terms of the cumulative impacts that it could have on forests, as well as the molestation of imago in cities that have been frequently reported. Since the pest is still a new element of a biocoenosis, there is a lack of research on its natural enemies and competitors that could form a potential foundation for biological control strategies. Although there have been reports that lace bugs are quite susceptible to a fungal diseases amid more humid conditions, to date, none of the pathogenic fungi found on OLBs under natural conditions were identified in the literature. In this study, we provide evidence of four entomopathogenic fungi: Beauveria pseudobassiana, Lecanicillium pissodis, Akanthomyces attenuatus and Samsoniella alboaurantium that could present a potential as biological control agents against OLBs.

\begin{abstract}
The oak lace bug (OLB), Corythucha arcuata (Hemiptera: Tingidae), was first identified as an invasive pest in Europe in northern Italy in 2000 and since then it has spread rapidly, attacking large forested areas in European countries. The OLB is a cell sap-sucking insect that is native to North America, with Quercus spp. as its main host. Its rapid expansion, successful establishment in invaded countries, and observations of more damage to hosts compared to native areas are most likely due to a lack of natural enemies, pathogens and competitors. In its native area, various natural enemies of OLBs have been identified; however, little is known about the occurrence and impact of OLB pathogens. None of the pathogenic fungi found on OLBs in natural conditions have been identified until now. In this study, we provide evidence of four entomopathogenic fungi that are naturally occurring on invasive OLBs found in infested pedunculate oak forests in eastern Croatia. On the basis of their morphology and multilocus molecular phylogeny, the fungi were identified as Beauveria pseudobassiana, Lecanicillium pissodis, Akanthomyces attenuatus and Samsoniella alboaurantium. The sequences generated for this study are available from GenBank under the accession numbers MT004817-MT004820, MT004833-MT004835, MT027501-MT27510, and MT001936-MT0011943. These pathogenic species could facilitate biological control strategies against OLBs.
\end{abstract}


Keywords: Beauveria pseudobassiana; Akanthomyces attenuatus; Lecanicillium pissodis; Samsoniella alboaurantium; oak forests; morphology; molecular phylogeny; Croatia

\section{Introduction}

The oak lace bug, Corythucha arcuata (Say, 1832) (Hemiptera: Tingidae), is a cell sap-sucking pest native to North America and a common and important pest of Quercus spp. [1,2]. It was recorded in Europe for the first time in 2000 in northern Italy [3], and it has now spread to other countries such as Turkey [4], Switzerland [5], Iran [6], Bulgaria [7], Croatia [8], Hungary [9], Serbia [10], Romania [11,12], Russia [13], Slovenia [14], Bosnia and Herzegovina [15], France [16], Slovakia [17] and Austria [18].

This invasive species spread is a result of a combination of different factors, such as translocation with plants or other goods by trade and transport, or movement with humans and traffic vehicles along transport routes or within towns [2]. The main hosts in Europe are oaks, with outbreak populations found most frequently on Quercus robur (L.), Q. petraea (Matt.) Liebl, Q. frainetto (Ten.) and Q. cerris (L.) [19]. Besides oaks, Castanea sativa (Mill.), Rosa canina (L.), Rubus idaeus (L.), R. fruticosus (L.), Malus sylvestris (L.) Mill. and Ulmus minor (Mill.) are also mentioned as a host plants [8,20].

Both nymphs and adults of OLBs feed directly on leaves by piercing and sucking the nutritious fluid from the cells between the upper and lower epidermis of the leaves, which can cause chlorosis, discoloration and desiccation of the leaf surface, reduction in photosynthesis and even premature leaf fall $[7,21,22]$.

It is not yet known if OLBs cause host mortality, but the pest has reached very high population levels in some European countries such as Croatia; this is worrying in terms of the cumulative impacts that it could have on forests [23]. Since its first appearance in eastern Croatia, in lowland stands of pedunculate oak [8] it still occurs with the same intensity and is still spreading to the west and north, causing stress to already susceptible valuable oak stands [14,15,17]. Another aspect of the rising OLB problem in Croatia is accidental contact with imago that fall on human skin. So far, there have been no reports of systemic health effects on humans, but it has been shown that the closely related C. ciliata (Aay, 1832) can be an agent of insect-caused dermatosis [24]. Bites and irritation of OLBs have been frequently reported in Croatian cities [25] and mentioned as a new problem in Romania [26].

Their rapid expansion and successful establishment in the invaded countries, and the observation of more damage on hosts in its introduced range than in its original range are probably due to the absence of natural enemies and competitors. The natural enemies of OLBs in their native area include assassin bugs, spiders and lady beetles [27], but there is a lack of research on their impact in European countries, where the pest is still a new element of a biocoenosis. Although there have been reports that lace bugs are quite susceptible to a fungal diseases in humid conditions [28], to date, none of the pathogenic fungi found on OLBs under natural conditions were isolated and identified in the literature.

There are several invasive insect pests in forest ecosystems that have been targets of various management practices, including microbial control with native or introduced entomopathogens [29]. The biological control of pests by using entomopathogenic fungi is an attractive alternative to the use of chemical pesticides, mainly because these fungi are safer for humans, animals, and the environment [30]. More than 700 fungal species from 100 orders are estimated as potential bioagents; however, a majority of important insect pathogens belong to the phylum Ascomycota and order Hypocreales, as well as to Entomophthoromycota, order Entomophthorales [29,31]. The search for virulent fungal isolates against a target host preferably begins with the resident (native) antagonists, because these will be adapted for survival in the target environment. In Croatia, an isolate of naturally occurring entomopathogenic fungus B. bassiana that was obtained from Dendrolimus pini L. (Lepidoptera, Lasiocampidae) cadavers was tested against $D$. pini healthy larvae and showed promising potential as a biocontrol agent [32].

Biological control has never been seriously attempted with OLBs. However, in vitro experiments which artificially inoculated entomopathogenic fungi spore suspensions on OLB nymphs and adults 
have been performed, where B. bassiana showed the highest mortality rate $(80 \%$ and $90 \%)$ with mycosis values of $77 \%$ and $83 \%$ [33]. As OLB nymphs and imago live on the underside of leaves, where they actively move, the transmission of pathogens between them shall be theoretically possible.

The aim of this study was to identify the spectrum of entomopathogenic fungi that naturally occur on OLBs in severely affected oak forests in Croatia. This included both morphological and molecular identification, and phylogenetic analysis, to compare the positions of the obtained strains with the strains obtained from different insects. The species found could form a potential foundation for biological control strategies of OLBs.

\section{Materials and Methods}

\subsection{Specimen Collection and Fungi Isolation}

Corythucha arcuata adults were collected in May 2018, from moss on trees where one part of the population usually overwinters. The chosen area was an infested pedunculate oak forest in the Spačva

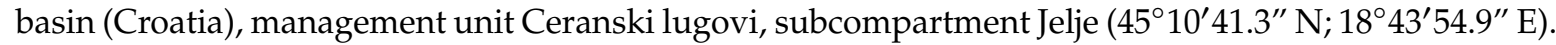
In the Spačva basin, the fungal infection of C. arcuata can be found on up to $18 \%$ of individuals per $1 \mathrm{~m}^{2}$ of moss [34]. To assay the presence and characteristics of entomopathogenic fungi, $15 \mathrm{dead}$ specimens with visible mycosis were brought to the Laboratory of Phytopathology Analysis at the Croatian Forest Research Institute. The naturally infected dead specimens were transferred from the field to the laboratory in Eppendorf tubes and were put in a moist chamber for a further stimulation for fungal sporulation. All cadavers with characteristic symptoms of mycosis were examined under a dissecting microscope $(40 \mathrm{X})$ to detect possible contaminants or death caused by other factors. After a few days, fungal isolation was made from developed or sporulating mycelia from C. arcuata cadavers on potato dextrose agar (PDA) medium. The cultures were incubated for $1-2$ weeks at $25 \pm 1{ }^{\circ} \mathrm{C}$, to facilitate growth and sporulation. Then, all isolates were subcultured from a single colony to acquire axenic colonies.

\subsection{Morphological Characterization}

The infected individuals were recognized according to the presence of mycelial growth on the outside of the cadaver [35]. The in vitro cultures were microscopically identified according to the morphology of microstructures [36-38]. A characterization of fungal isolates was made by the determination of conidial size and shape, conidiogenous cell and colony morphology. For each isolate, a width and length of 100 conidia and conidiogenous cells from a 14-day-old cultures were measured by using a phase-contrast microscope (Olympus, model BX53, Tokyo, Japan) and magnification 400×, following Inglis et al. [39]. Microscopic images of fungal structures were taken with digital camera (Leica, model MC170 HD, Wetzlar, Germany) mounted on a microscope (Leica, model DM3000 LED, Wetzlar, Germany). Macroscopic images of infected insects were taken under a dissecting microscope (Olympus, model SZX7, Tokyo, Japan) with an Olympus XC30 (Tokyo, Japan) camera and images of fungal colonies were taken with Olympus E-30 (Tokyo, Japan) camera. The twelve fungal cultures were deposited in the Laboratory of Phytopathological Analysis at the Croatian Forest Research Institute (Jastrebarsko, Croatia) and the Institute of Evolutionary Biology at the Faculty of Biology, University of Warsaw under voucher numbers BBNK1, BBNK2, BBC1-BBC10.

\subsection{DNA Isolation, Polymerase Chain Reaction (PCR) Amplification and Sequencing}

Total genomic DNA was isolated from fresh plate cultures of all 12 fungal isolates used in this study by using an ExtractMe Genomic DNA Kit (Blirt S.A., Gdańsk, Poland) following the manufacturer's instructions. Two molecular markers were amplified for the Beauveria strains: the nuclear ribosomal DNA (rDNA) internal transcribed spacer region (ITS1-5.8S-ITS2 = ITS) and the nuclear intergenic region Bloc. For the other Cordycipitaceae strains, seven molecular markers were amplified: internal transcribed spacer (ITS), nuclear rDNA small subunit (SSU or 18S) and large subunit (LSU or 28S), 
and three nuclear protein-encoding genes, translation elongation factor-1a (TEF), the RNA polymerase II largest subunit (RPB1) and the RNA polymerase II second-largest subunit (RPB2). The primers used are listed in the Table 1.

Table 1. Polymerase Chain Reaction (PCR) and sequencing primers used, with references.

\begin{tabular}{cccc}
\hline Locus & Forward & Reverse & Source \\
\hline ITS & ITS1F & ITS4 & Gardes and Bruns, 1993 [40]; White et al., 1990 [41] \\
SSU & NS1 & NS6 & White et al., 1990 [41] \\
LSU & LR0R & LR5 & Vilgalys, unpublished; Vilgalys and Hester, 1990 [42] \\
TEF & EF1-983F & EF1-2218R & Rehner and Buckley, 2005 [36] \\
RPB1 & CRPB1 & RPB1-Cr & Castlebury et al., 2004 [43]; Matheny et al., 2002 [44] \\
RPB2 & RPB2-5F1 & RPB2-7cR & Sung et al., 2007 [45]; Reeb et al., 2004 [46] \\
Bloc & B5.1F & B3.1R & Rehner et al., 2006 [47] \\
\hline
\end{tabular}

PCR conditions for Bloc and TEF were as follow: initial denaturation at $95^{\circ} \mathrm{C}$ for $2 \mathrm{~min}, 34$ cycles of $95^{\circ} \mathrm{C}$ for $30 \mathrm{~s}, 56^{\circ} \mathrm{C}$ for $30 \mathrm{~s}, 72{ }^{\circ} \mathrm{C}$ for $2 \mathrm{~min}$ and final elongation at $72{ }^{\circ} \mathrm{C}$ for $10 \mathrm{~min}$. For other loci, the following conditions were set: initial denaturation at $95^{\circ} \mathrm{C}$ for $5 \mathrm{~min}, 34$ cycles of $95^{\circ} \mathrm{C}$ for $15 \mathrm{~s}, 52^{\circ} \mathrm{C}\left(48^{\circ} \mathrm{C}\right.$ for RPB2) for $30 \mathrm{~s}, 72{ }^{\circ} \mathrm{C}$ for $1.5 \mathrm{~min}$ and final elongation at $72{ }^{\circ} \mathrm{C}$ for $7 \mathrm{~min}$. PCR products were purified with the ExtractMe DNA Clean-up and Gel-out Kit (Blirt S.A., Gdańsk, Poland) and later sequenced with the ABI PRISM Big Dye Terminator Cycle Sequencing Ready Reaction Kit 3.1 (Applied Biosystems, Warrington, UK) with the same primers as in the PCR reaction. The sequences generated for this study are available from GenBank under the accession numbers MT004817-MT004820, MT004833-MT004835, MT027501-MT27510, and MT001936-MT0011943 (Supplementary Materials Table S1).

\subsection{Phylogenetic Analysis}

Sequences were assembled using Lasergene v15 (DNASTAR, Inc., Madison, WI, USA), and combined with sequences obtained from Genebank (Supplementary Materials Table S1). For the Beauveria strains, we used a backbone tree from Imoulan et al. [48], and for the wider Cordycypitaceae phylogeny we used a backbone tree from Zhou et al. [49] with sequences of Paecilomyces hepiali Q.T. Chen and R.Q. Dai ex R.Q. Dai et al. (Cordycipitaceae, Hypocreales) added. Multiple sequence alignments were conducted using MAFFT v7.271 [50] and trimmed with trimAI 1.2rev59 [51] or, for protein coding sequences, Gblocks 0.91b [52]. The trimmed alignments were partitioned according to molecular markers, and, in case of protein-coding loci, the codon position was also partitioned. Maximum likelihood trees were generated with RAxML-NG v. 0.8.0 [53].

\section{Results}

\subsection{Isolation and Morphological Identification of Fungi}

A total of 12 fungal isolates were obtained from naturally infected C. arcuata adults collected from the field. On the basis of morphological features, we identified these species as Beauveria pseudobassiana (S.A. Rehner and Humber), Lecanicillium pissodis (Kope and I. Leal), Akanthomyces attenuatus (Zare and W. Gams) (Spatafora, Kepler and B. Shrestha) and Samsoniella alboaurantium (G. Sm.) (Mongkols., Noisrip., Thanakitp., Spatafora and Luangsa-ard) (Figure 1a-d). B. pseudobassiana was the most commonly detected fungus with eight isolates altogether $(\mathrm{BBC} 1, \mathrm{BBC} 2, \mathrm{BBC} 3, \mathrm{BBC} 4, \mathrm{BBC} 6, \mathrm{BBC} 8, \mathrm{BBC} 10$ and $\mathrm{BBNK} 1)$. Isolates BBNK2 and BBC7 were identified as L. pissodis, isolate BBC9 as A. attenuatus, and isolate BBC5 was identified as S. alboaurantium. The morphological characteristics of the fungal species used in this study are summarized in Table 2.

\subsection{Phylogenetic Analysis}

As shown in Figure 2, the strains BBC1 to BBC4, BBC6, BBC8, BBC10 and BBCNK1 clustered with reference $B$. pseudobassiana strains. Strains BBCNK2, BBC7 and BBC9 formed a weakly resolved clade 
with species of L. pissodis, A. muscarius and A. attenuatus, and their identities were clarified according to their morphologies. Strain BBC5 clustered with S. alboaurantium (Figure 3).
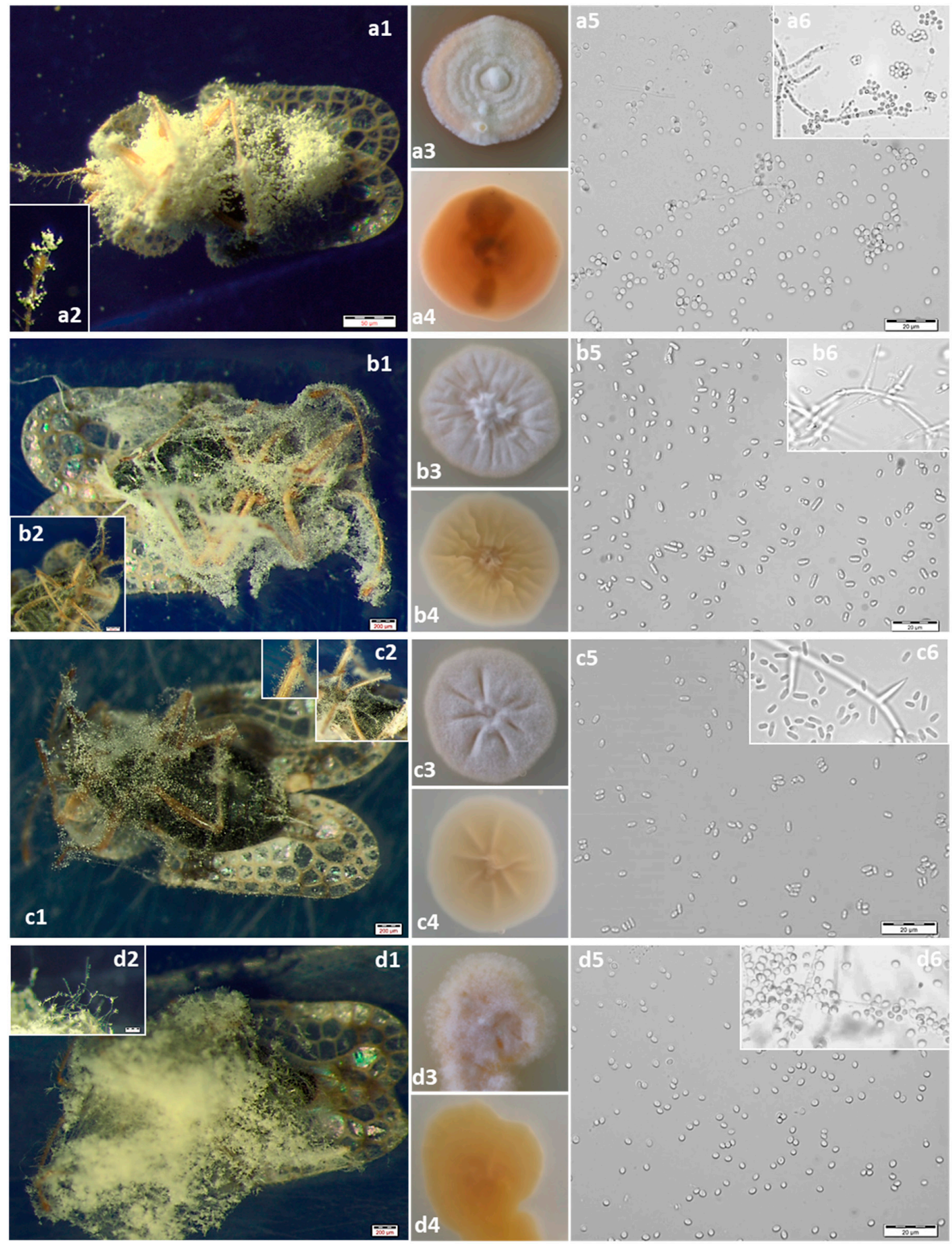

Figure 1. (a) Beauveria pseudobassiana: (a1) Infected adult of C. arcuata. (a2) Conidiophores. (a3) Colony on potato dextrose agar (PDA) at $14 \mathrm{~d}$. obverse. (a4) Colony on PDA at $14 \mathrm{~d}$. reverse. (a5) Conidia. (a6) Conidiogenous cells. (b) Akanthomyces attenuatus: (b1) Infected adult of C. arcuata. (b2) Conidiophores. (b3) Colony on PDA at $14 \mathrm{~d}$. obverse. (b4) Colony on PDA at $14 \mathrm{~d}$. reverse. (b5) Conidia. (b6) Conidiogenous cells. (c) Lecanicillium pissodis: (c1) Infected adult of C. arcuata. (c2) Conidiophores. (c3) Colony on PDA at $14 \mathrm{~d}$. obverse. (c4) Colony on PDA at $14 \mathrm{~d}$. reverse. (c5) Conidia. (c6) Conidiogenous cells. (d) Samsoniella alboaurantium: (d1) Infected adult of C. arcuata. (d2) Conidiophores. (d3) Colony on PDA at $14 \mathrm{~d}$. obverse. (d4) Colony on PDA at $14 \mathrm{~d}$. reverse. (d5) Conidia. (d6) Conidiogenous cells. 


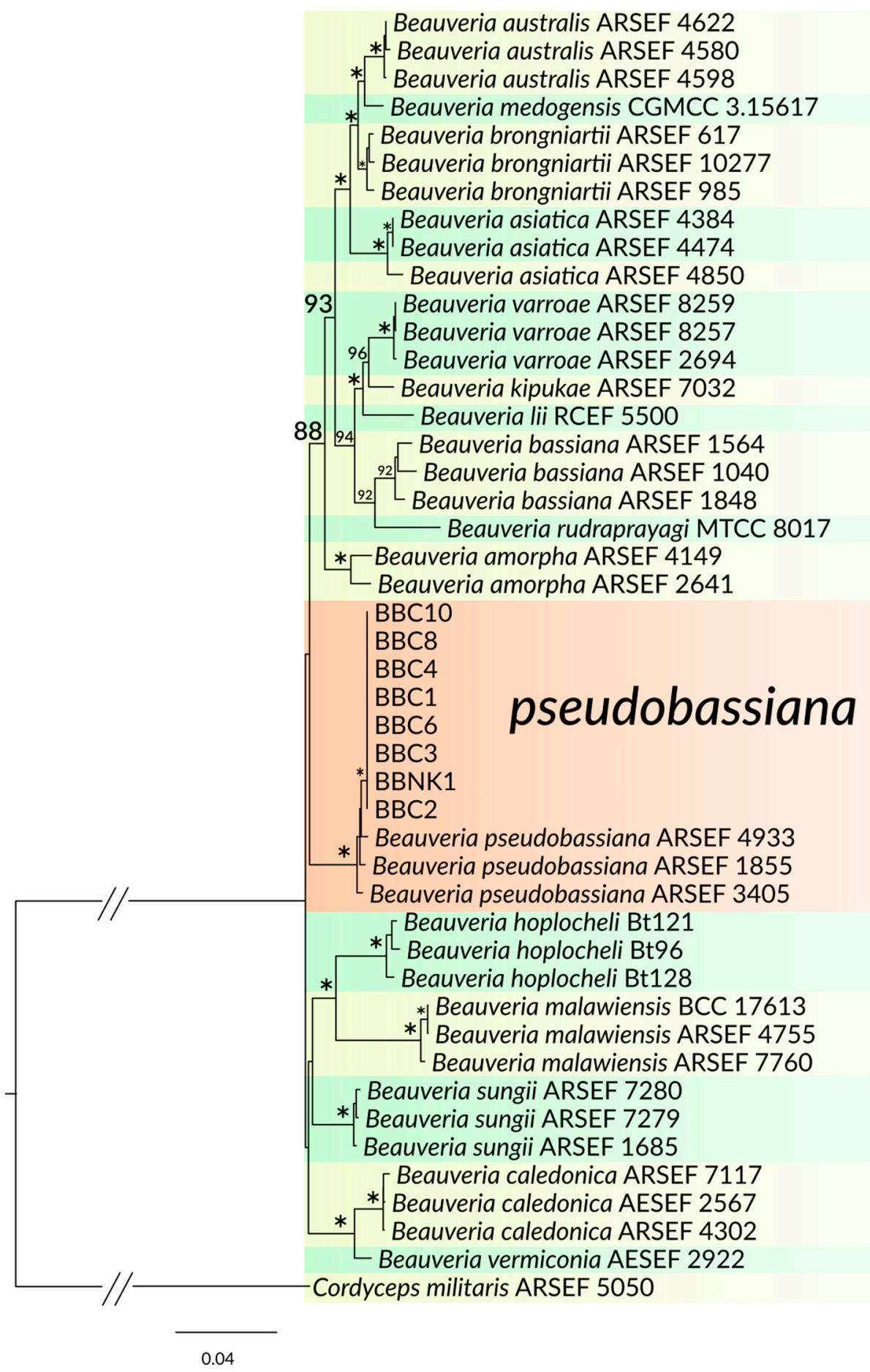

Figure 2. Maximum likelihood phylogenetic tree of selected isolated strains and related Beauveria species based on five loci (internal transcribed spacer (ITS)+Bloc+ translation elongation factor-1a $(\mathrm{TEF})+\mathrm{RPB} 1+\mathrm{RPB} 2)$. Clades with newly isolated strains are highlighted in orange. Only bootstraps over $80 \%$ are shown. A bootstrap of $100 \%$ is indicated with an asterisk. 


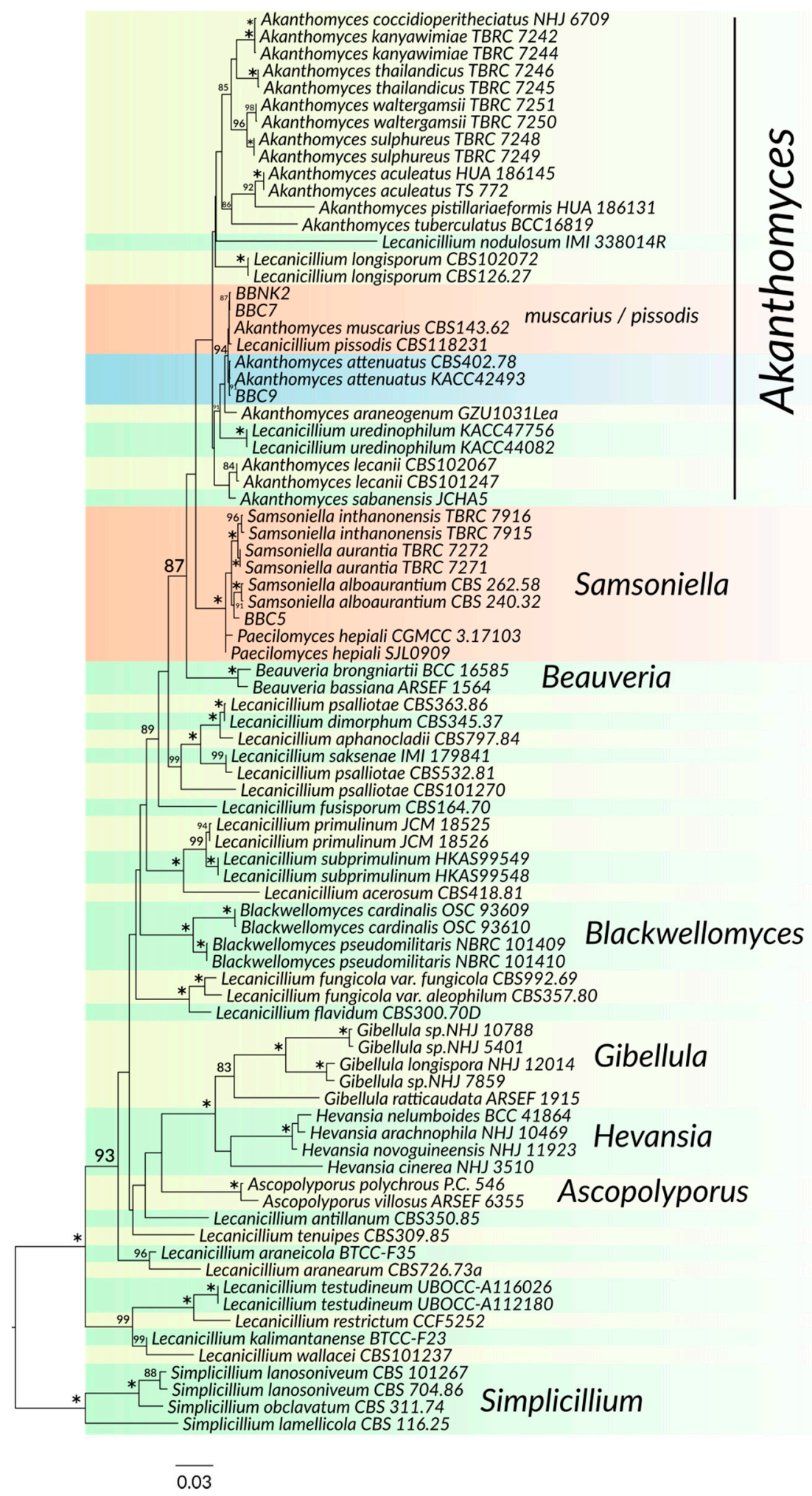

Figure 3. Maximum likelihood phylogenetic tree of the isolated strains $\mathrm{BBC} 5, \mathrm{BBC} 7, \mathrm{BBC} 9$ and $\mathrm{BBCNK} 2$ and related Cordycypitaceae species derived from a combined dataset of ITS+SSU+LSU+TEF+RPB1+RPB2 sequences. Clades with newly isolated strains are highlighted in orange and blue. Only bootstraps over $80 \%$ are shown. A bootstrap of $100 \%$ is indicated with the asterisk. 
Table 2. Summary of the main morphological characteristics of four recognized fungal species found on Corythucha arcuata.

\begin{tabular}{|c|c|c|c|c|}
\hline Isolate & Species & Colonies & Conidiogenous Cell & Conidial Shape and Size \\
\hline $\begin{array}{c}\text { BBC1 } \\
\text { BBC2 } \\
\text { BBC3 } \\
\text { BBC4 } \\
\text { BBC6 } \\
\text { BBC8 } \\
\text { BBC10 } \\
\text { BBNK1 }\end{array}$ & $\begin{array}{c}\text { Beauveria } \\
\text { pseudobassiana }\end{array}$ & $\begin{array}{l}\text { white first and becoming } \\
\text { yellowish-brown or pale yellow, } \\
\text { aerial mycelium dense and } \\
\text { farinaceous during sporulation, } \\
\text { sometimes producing exudate, } \\
\text { slightly changing color of } \\
\text { medium to light purple; reverse } \\
\text { side yellowish-brown with } \\
\text { white margin }\end{array}$ & $\begin{array}{l}\text { conidiophores solitary but } \\
\text { usually consisting of dense } \\
\text { spherical lateral clusters of } \\
\text { globose to flask-shaped } \\
\text { conidiogenous cells with an } \\
\text { elongating sympodial } \\
\text { denticulate rachis giving a } \\
\text { zig-zag appearance, } \\
3-6 \times 1.3-2.5 \mu \mathrm{m}\end{array}$ & $\begin{array}{l}\text { globose to subglobose, rarely } \\
\text { ellipsoid, 1-celled, hyaline, } \\
\text { smooth-walled; } \\
2.5-3.7 \times 1.4-3.1 \mu \mathrm{m}\end{array}$ \\
\hline BBC5 & $\begin{array}{l}\text { Samsoniella } \\
\text { alboaurantium }\end{array}$ & $\begin{array}{c}\text { white to light orange, cottony } \\
\text { and floccose; reverse side } \\
\text { deep yellow }\end{array}$ & $\begin{array}{l}\text { conidiophores biverticillate } \\
\text { with whorls of flask shaped } \\
\text { phialides, } 5.7-10 \times 1.5-3 \mu \mathrm{m}\end{array}$ & $\begin{array}{l}\text { conidia lemonshaped, } 1 \text {-celled, } \\
\text { hyaline, smooth walled, } \\
2-3.5 \times 1.9-3.5 \mu \mathrm{m} \text {, sometimes } \\
\text { in chains }\end{array}$ \\
\hline $\begin{array}{c}\text { BBC7 } \\
\text { BBNK2 }\end{array}$ & $\begin{array}{l}\text { Lecanicillium } \\
\text { pissodis }\end{array}$ & $\begin{array}{l}\text { white; reverse side cream to } \\
\text { pale yellow }\end{array}$ & $\begin{array}{l}\text { phialides solitary, or } 2 \text { to } 3 \text { in } \\
\text { whorls, } 12.6-38 \times 1-2 \mu \mathrm{m}\end{array}$ & $\begin{array}{l}\text { formed in globose droplets } \\
\text { containing up to more than } 50 \\
\text { spores, cylindrical to oval, } \\
\text { variable in size and shape, } \\
2.6-7.2 \times 1.7-2.5 \mu \mathrm{m}\end{array}$ \\
\hline BВC9 & $\begin{array}{l}\text { Akanthomyces } \\
\text { attenuates }\end{array}$ & $\begin{array}{l}\text { white; reverse side } \\
\text { yellowish-white }\end{array}$ & $\begin{array}{l}\text { up to } 3-5 \text { per node, } \\
9.3-15.8 \times 1-2 \mu \mathrm{m}\end{array}$ & $\begin{array}{c}\text { cylindrical with slightly } \\
\text { narrowed base, sometimes } \\
\text { oval, very variable in size and } \\
\text { shape } 2.3-6 \times 1.5-2.9 \mu \mathrm{m}\end{array}$ \\
\hline
\end{tabular}

\section{Discussion}

In this study, we report the evidence of four entomopathogenic fungi occurring on invasive OLBs found in an infested pedunculate oak forest in eastern Croatia. On the basis of their morphologies and multilocus molecular phylogenies, an identification of naturally occurring entomopathogenic fungi was performed. This is the first report of the occurrence of B. pseudobassiana, L. pissodis, A. attenuatus and S. alboaurantium on OLBs in oak forests.

Beauveria species are the most common cosmopolitan insect-pathogenic fungi which parasitize over 700 insect species [48,54]. Until now, five species (B. bassiana, B. brongniartii, B. caledonica, B. varroae and B. pseudobassiana) have been documented in Europe [53]. Beauveria pseudobassiana is an entomopathogenic fungus with a worldwide distribution, and it can be pathogenic to a wide range of hosts $[37,55,56]$. Recent analyses of soil samples in Slovakia have indicated that B. pseudobassiana prefers forest habitats over field crops or meadows [57], assumed to be due to its better adaptation to forest ecosystems. It was first described, i.e., distinguished from B. bassiana, in 2011 by DNA-based phylogenetic analysis. Since these two species are morphologically similar and could only be differentiated by B. pseudobassiana possessing slightly smaller conidia, it was believed that their distinction is only possible through DNA sequence data analysis [37]. More recent research morphologically also separates them by their colony color, where the B. bassiana colony was described as being white, and B. pseudobassiana as being yellowish-brown [49], which coincides with the findings of this research. Moreover, we noted that our B. pseudobassiana isolates slightly changed the color of the nutrient medium to light purple during their growth, which was not recorded in previous studies. This is probably due to some species or strains of Beauveria being able to produce specific secondary metabolites that can change the color of some culture media $[58,59]$.

Entomopathogenic fungi species belonging to the genus Lecanicillium have a global distribution, occur on a diverse range of insect species, and have potential for development as effective biological control agents against a number of plant diseases, insect pests and plant-parasitic nematodes [60]. For the species L. pissodis and L. attenuatum, the ITS sequences were identical, but in 2005, they were distinguished by a $\beta$-tubulin gene sequence. They can also be discriminated from each other and from other Lecanicillium species by differences in morphology [61]. In 2015, some species of Lecanicillium, including L. attenuatum, fell within the genus Akanthomyces [62], and according to Kepler et al. [63], 
L. attenuatum was renamed Akanthomyces attenuatus. Despite dubious points in the phylogeny for strains BBNK2, BBC7 and BBC9 in this study, their identities were resolved based on their different morphological characteristics. According to their growth rates in culture, phialides morphologies and conidial shapes and sizes, the strains BBNK2 and BBC7 were identified as being L. pissodis, and strain BBC9 was identified as being A. attenuatus.

At the initial stages of molecular identification, the ITS sequence of the BBC5 strain was found to be highly similar to that of the Paecilomyces hepiali-type strain (99.8\% identity). Because of this, we decided to add P. hepiali to our phylogenetic analysis, and it clustered as an outmost branch of the Samsoniella clade. Although P. hepiali is intensively researched as medicinal fungus, there is some uncertainty about its taxonomical placement. Only a few sequences are available from ex-type cultures or wrongly designated neotypes [64,65]. Moreover, P. hepiali has not been included in any major molecular phylogenetic studies on Cordycypitaceae. As far as we know, this study is the first to demonstrate that P. hepiali and Samsoniella are closely related. Samsoniella was segregated from Lecanicillium s.l. and, based on molecular evidence in 2018 , S. alboaurantium was originally identified as Penicillium alboaurantium by Samson [66], which was affiliated to this newly established genus [67].

\section{Conclusions}

Since reports that are related to natural enemies of OLBs are quite limited, especially considering the pathogenic nature of the fungi towards OLBs, the findings of this study provide a good foundation for similar research in the future. Future studies are still required in order to evaluate the potential of these fungi as a group of biological control agents against OLBs. This should include testing their efficacy, both in laboratory conditions and in their natural habitat in order for them to be involved as a component in control strategies.

Supplementary Materials: The following are available online at http://www.mdpi.com/2075-4450/11/10/679/s1, Table S1: Genbank accession numbers of sequences used in the phylogenetic analysis.

Author Contributions: M.K. and M.P. conceived and designed research; M.K. performed the field sampling; C.T. and M.K. were responsible for the morphological identification; M.G. was responsible for the molecular work and data analysis under supervision of M.W.; M.K. wrote the first draft, but all authors equally contributed to the revision of the manuscript. All authors have read and agreed to the published version of the manuscript.

Funding: The research was supported by the National Science Centre, Poland, under grant 2016/23/B/NZ8/00897 (PI: Marta Wrzosek) and by the Diagnostic and Prognostic Service (IPP) of the Croatian Forest Research Institute (Jastrebarsko).

Acknowledgments: We thank Marta Wrzosek's group from the Department of Molecular Phylogenetics and Evolution at Faculty of Biology (University of Warsaw, Poland) for all their assistance and help during lab work.

Conflicts of Interest: The authors declare no conflict of interest.

\section{References}

1. Drake, C.J.; Ruhoff, F.A. Lacebugs of the world, a Catalog (Hemiptera: Tingidae). Bull. US Natl. Mus. 1965, 243, 1-634. [CrossRef]

2. Rabitsch, W. Alien true bugs of Europe (Insecta: Hemiptera: Heteroptera). Zootaxa 2008, 1827, 1-44. [CrossRef]

3. Bernardinelli, I.; Zandigiacomo, P. Prima segnalazione di Corythucha arcuata (Say) (Heteroptera, Tingidae) in Europa. Inf. Fitopatol. 2000, 50, 47-49.

4. Mutun, S. First report of the oak lace bug, Corythucha arcuata (Say, 1832) (Heteroptera: Tingidae) from Bolu, Turkey. Isr. J. Zool. 2003, 33, 263-268.

5. Forster, B.; Giacalone, I.; Moretti, M.; Dioli, P.; Wermelinger, B. Die amerikanische Eichennetzwanze Corythucha arcuata (Say) (Heteroptera, Tingidae) hat die Süsschweiz erreicht. Mitt. Schweiz. Entomol. Ges. 2005, 78, 317-323.

6. Samin, N.; Linnavuori, R.E. A contribution to the Tingidae (Heteroptera) from north and northwestern Iran. Entomofauna 2011, 32, 373-380. 
7. Dobreva, M.; Simov, N.; Georgiev, G.; Mirchev, P.; Georgieva, M. First Record of Corythucha arcuata (Say) (Heteroptera: Tingidae) on the Balkan Peninsula. Acta Zool. Bulg. 2013, 3, 409-412.

8. Hrašovec, B.; Posarić, D.; Lukić, I.; Pernek, M. Prvi nalaz hrastove mrežaste stjenice (Corythucha arcuata) u Hrvatskoj. Sumar. List 2013, 137, 499-503.

9. Csóka, G.; Hirka, A.; Somlyai, M. A tölgy csipkéspoloska (Corythuca arcuata Say, 1832-Hemiptera, Tingidae) elsô észlelése Magyarországon. Növényvédelem 2013, 49, 293-296.

10. Pap, P.; Drekić, M.; Poljaković-Pajnik, L.; Marković, M.; Vasić, V. Monitoring zdravstvenog stanja šuma na teritoriji Vojvodine u 2015. godini. Topola Poplar 2015, 188, 117-133.

11. Don, I.; Don, C.D.; Sasu, L.R.; Vidrean, D.; Brad, M.L. Insect pests on the trees and shrubs from the Macea Botanical Garden. Studia Univ. Vasile Goldis Arad 2016, 11, 23-28.

12. Chireceanu, C.; Theodoru, A.; Chiriloaie, A. First record of oak lace bug Corythucha arcuata (Tingidae: Heteroptera). In Proceedings of the 7th ESENIAS Workshop with Scientific Conference Networking and Regional Cooperation towards Invasive Alien Species Prevention and Management in Europe, Sofia, Bulgaria, 28-30 March 2017.

13. Shchurov, V.I.; Bondarenko, A.S.; Skvortsov, M.M.; Shchurova, A.V. The alien invasive forest insect pests for the first time revealed in forest ecosystems of the Northwest Caucasus in 2014-2016. In The Kataev Memorial Readings - IX Dendrobiotic Invertebrates and Fungi and their Role in Forest Ecosystems, Proceedings of the International Conference, Saint Petersburg, Russia, 23-25 November 2016; Musolin, D.L., Selikhovkin, A.V., Eds.; Saint Petersburg State Forest Technical University: Saint Petersburg, Russia, 2016.

14. Jurc, M.; Jurc, D. The first record and the beginning of the spread of oak lace bug, Corythucha arcuata (Say, 1832) (Heteroptera: Tingidae), in Slovenia. Sumar. List 2017, 141, 485-488. [CrossRef]

15. Dautbašić, M.; Zahirović, K.; Mujezinović, O.; Margaletić, J. First record of oak lace bug (Corythucha arcuata) in Bosnia and Herzegovina. Sumar. List 2018, 142, 179-181. [CrossRef]

16. Streito, J.C.; Balmès, V.; Aversenq, P.; Weill, P.; Chapin, E.; Clément, M.; Piednoir, F. Corythucha arcuata (Say, 1832) et Stephanitis lauri Rietschel, 2014, deux espèces invasives nouvelles pour la faune de France (Hemiptera, Tingidae). L'Entomologiste 2018, 74, 133-136.

17. Zúbrik, M.; Gubka, A.; Rell, S.; Kunca, A.; Vakula, J.; Galko, J.; Nikolov, C.; Leontovyč, R. First record of Corythucha arcuata in Slovakia-Short Communication. Plant. Prot. Sci. 2019, 55, 129-133. [CrossRef]

18. Sallmannshofer, M.; Ette, M.S.; Hinterstoisser, W.; Cech, T.L.; Hoch, G. Erstnachweis der Eichennetzwanze, Corythucha arcuata, in Österreich. Aktuell 2019, 66, 1-6.

19. György Csóka, G.; Hirka, A.; Mutun, S.; Glavendeki, M.; Mikó, A.; Szőcs, L.; Paulin, M.; Csaba Béla Eötvös, C.B.; Gáspár, C.; Csepelényi, M.; et al. Spread and potential host range of the invasive oak lace bug [Corythucha arcuata (Say, 1832)—Heteroptera: Tingidae] in Eurasia. Agr. For. Entomol. 2019, 22, 61-74. [CrossRef]

20. Bernardinelli, I. Potential host plants of Corythucha arcuata (Het., Tingidae) in Europe: A laboratory study. J. Appl. Entomol. 2006, 130, 480-484. [CrossRef]

21. Connell, W.A.; Beacher, J.H. Life history and control of the oak lace bug. Bull. Univ. Del. Agric. Exp. Stn. 1947, 265, 28.

22. Mutun, S.; Ceyhan, Z.; Sözen, C. Invasion by the oak lace bug, Corythucha arcuata (Say) (Heteroptera: Tingiᄀdae), in Turkey. Turk. J. Zool. 2009, 49, 323-324. [CrossRef]

23. UK Government Department for Environment, Food and Rural Affairs (Defra). Rapid Pest Risk Analysis (PRA) for: Corythucha arcuata. November 2018; UK government Department for Environment, Food and Rural Affairs (Defra): London, UK, 2018.

24. Dutto, M.; Bertero, M. Dermatosis caused by Corythuca ciliata (Say, 1932) (Heteroptera, Tingidae). diagnostic and clinical aspects of an unrecognized pseudoparasitosis. J. Prev. Med. Hyg. 2009, 54, 57-59.

25. Pernek, M.; (Croatian Forest Research Institute, Jastrebarsko, Croatia). Personal communication, 2019.

26. Ciceoi, R.; Radulovici, A. Facultative blood-sucking lace bugs, Corythucha sp. in Romania. In Joint ESENIAS and DIAS Scientific Conference and 8th ESENIAS Workshop, Book of Abstracts Management and Sharing of IAS Data to Support Knowledge Based Decision Making at Regional Level, Bucharest, Romania, 26-28 September 2018; Anastasiu, P., Trichkova, T., Uludag, A., Tomov, R., Eds.; Editura Universitatii din Bucuresti: Bucharest, Romania, 2018.

27. Dreistadt, S.H.; Perry, E.J. Lace Bugs: Integrated pest management for home gardeners and lascape professionals. Pest Notes Univ. Calif. Agric. Nat. Resour. Bull. 2006, 74, 1-4. 
28. Dreistadt, S.H.; (UC Statewide IPM Program, Agriculture \& Natural Resources, University of California, Davis, CA, USA). Personal communication, 2019.

29. Dara, S.K.; Motlava, C.; Barta, M. Microbial control of invasive forest pests with entomopathogenic fungi: A review of the current situation. Insects 2019, 10, 341. [CrossRef] [PubMed]

30. Khetan, S.K. Microbial Pest Control; Marcel Dekker: New York, NY, USA, 2001; p. 320.

31. Augustyniuk-Kram, A.; Kram, K.J. Forest Ecosystems-More than Just Trees, Entomopathogenic Fungi as an Important Natural Regulator of Insect Outbreaks in Forests (Review); Blanco, J.A., Lo, Y.H., Eds.; InTech: Rijeka, Croatia, 2012; pp. 265-294.

32. Kovač, M.; Lacković, N.; Pernek, M. Effect of Beauveria bassiana fungal infection on survival and feeding behavior of pine-tree lappet moth (Dendrolimus pini L.). Forests 2020, 11, 974.

33. Sönmez, E.; Demirbag, Z.; Demir, I. Pathogenicity of selected entomopathogenic fungal isolates against the oak lace bug, Corythucha arcuata Say. (Hemipteran: Tingidae), under controlled conditions. Turk. J. Agric. 2016, 40, 715-722.

34. Kovač, M.; Pernek, M. Field research on natural infestation of entomopathogenic fungi on overwintering Corythucha arcuata (Say) (Hemiptera: Tingidae). (manuscript in preparation).

35. Greenfield, M.; Gómez-Jiménez, M.I.; Ortiz, V.; Vega, F.E.; Kramer, M.; Parsa, S. Beauveria bassiana and Metarhizium anisopliae endophytically colonize cassava roots following soil drench inoculation. Biol. Control 2016, 95, 40-48. [CrossRef]

36. Rehner, S.A.; Buckley, E.P. A Beauveria phylogeny inferred from nuclear ITS and EF1- $\alpha$ sequences: Evidence for cryptic diversification and links to Cordyceps teleomorphs. Mycologia 2005, 97, 84-98. [CrossRef]

37. Rehner, S.A.; Minnis, A.M.; Sung, G.H.; Luangsa-ard, J.J.; Devotto, L.; Humber, R.A. Phylogeny and systematics of the anamorphic, entomopathogenic genus Beauveria. Mycologia 2011, 103, 1055-1073. [CrossRef]

38. Humber, R.A. Manual of Techniques in Invertebrate Pathology, Identification of Entomopathogenic Fungi; Lacey, L.A., Ed.; Academic Press: London, UK, 2012; pp. 151-187.

39. Inglis, G.D.; Enkerli, J.; Goettel, M.S. Manual of Techniques in Invertebrate Pathology. Laboratory Techniques Used for Entomopathogenic Fungi: Hypocreales Chapter VII; Lacey, L.A., Ed.; Academic Press: London, UK, 2012; pp. 189-253.

40. Gardes, M.; Bruns, T.D. ITS primers with enhanced specificity for basidiomycetes-application to the identification of mycorrhizae and rusts. Mol. Ecol. 1993, 2, 113-118. [CrossRef]

41. White, T.J.; Bruns, T.; Lee, S.; Taylor, J. PCR Protocols: A Guide to Methods and Applications; Academic Press: San Diego, CA, USA, 1990; pp. 315-322.

42. Vilgalys, R.; Hester, M. Rapid genetic identification and mapping of enzymatically amplified ribosomal DNA from several Cryptococcus species. J. Bacteriol. 1990, 172, 4238-4246. [CrossRef]

43. Castlebury, L.A.; Rossman, A.Y.; Sung, G.H.; Hyten, A.S.; Spatafora, J.W. Multigene phylogeny reveals new lineage for Stachybotrys chartarum, the indoor air fungus. Mycol. Res. 2004, 108, 864-872. [CrossRef] [PubMed]

44. Matheny, P.B.; Liu, Y.J.; Ammirati, J.F.; Hall, B.D. Using RPB1 sequences to improve phylogenetic inference among mushrooms (Inocybe, Agaricales). Am. J. Bot. 2002, 89, 688-698. [CrossRef] [PubMed]

45. Sung, G.H.; Hywel-Jones, N.L.; Sung, J.M.; Luangsa-ard, J.J.; Shrestha, B.; Spatafora, J.W. Phylogenetic classification of Cordyceps and the clavicipitaceous fungi. Stud. Mycol. 2007, 57, 5-59. [CrossRef] [PubMed]

46. Reeb, V.; Lutzoni, F.; Roux, C. Contribution of RPB2 to multilocus phylogenetic studies of the euascomycetes (Pezizomycotina, Fungi) with special emphasis on the lichen-forming Acarosporaceae and evolution of polyspory. Mol. Phylogenet. Evol. 2004, 32, 1036-1060. [CrossRef] [PubMed]

47. Rehner, S.A.; Posada, F.; Buckley, E.P.; Infante, F.; Castillo, A.; Vega, F.E. Phylogenetic origins of African and Neotropical Beauveria bassiana s.l. pathogens of the coffee berry borer, Hypothenemus hampei. J. Invertebr. Pathol. 2006, 93, 11-21. [CrossRef]

48. Imoulan, A.; Li, Y.; Wang, W.J.; El Meziane, A.; Yao, Y.J. New record of Beauveria pseudobassiana from Morocco. Mycotaxon 2016, 131, 913-923. [CrossRef]

49. Zhou, Y.M.; Zhi, J.R.; Ye, M.; Zhang, Z.Y.; Yue, W.B.; Zou, X. Lecanicillium cauligalbarum sp. nov. (Cordycipitaceae, Hypocreales), a novel fungus isolated from a stemborer in the Yao Ren National Forest Mountain Park, Guizhou. MycoKeys 2018, 43, 59-74. [CrossRef]

50. Katoh, K.; Standley, D.M. MAFFT multiple sequence alignment software version 7: Improvements in performance and usability. Mol. Biol. Evol. 2013, 30, 772-780. [CrossRef] 
51. Capella-Gutiérrez, S.; Silla-Martínez, J.M.; Gabaldón, T. trimAl: A tool for automated alignment trimming in large-scale phylogenetic analyses. Bioinformatics 2009, 25, 1972-1973. [CrossRef]

52. Castresana, J. Selection of conserved blocks from multiple alignments for their use in phylogenetic analysis. Mol. Biol. Evol. 2000, 17, 540-552. [CrossRef]

53. Kozlov, A.M.; Darriba, D.; Flouri, T.; Morel, B.; Stamatakis, A. RAxML-NG: A fast, scalable, and user-friendly tool for maximum likelihood phylogenetic inference. Bioinformatics 2019, 35, 4453-4455. [CrossRef] [PubMed]

54. Inglis, G.D.; Goettel, M.S.; Butt, T.M.; Strasser, H. Fungi as Biocontrol Agents: Progress, Problems and Potential; Butt, T.M., Jackson, C., Magan, N., Eds.; CABI Publishing: Wallingford, UK, 2001; pp. 23-69.

55. Barta, M.; Lalík, M.; Rell, S.; Kunca, A.; Horáková, M.K.; Mudronceková, S.; Galko, J. Hypocrealean fungi associated with Hylobius abietis in Slovakia, their virulence against weevil adults and effect on feeding damage in laboratory. Insects 2019, 10, 634. [CrossRef]

56. Schemmer, R.; Chládeková, P.; Medo, J.; Barta, M. Natural prevalence of entomopathogenic fungi in hibernating pupae of Cameraria ohridella (Lepidoptera: Gracillariidae) and virulence of selected isolates. Plant Prot. Sci. 2016, 52, 199-208.

57. Medo, J.; Michalko, J.; Medová, J.; Cagáň, L. Phylogenetic structure and habitat associations of Beauveria species isolated from soils in Slovakia. J. Invertebr. Pathol. 2016, 140, 46-50. [CrossRef]

58. De Hoog, G.S. The genera Beauveria, Isaria, Tritirachium, and Acrodontium gen. nov. Stud. Mycol. 1972, 1, 1-41.

59. Strasser, H.; Vey, A.; Butt, T.M. Are there any risks in using entomopathogenic fungi for pest control, with particular reference to the bioactive metabolites of Metarhizium, Tolypocladium and Beauveria species? Biocontrol Sci. Techn. 2000, 10, 717-735. [CrossRef]

60. Goettel, M.S.; Koike, M.; Kim, J.J.; Aiuchi, D.; Shinya, R.; Brodeur, J. Potential of Lecanicillium spp. for management of insects, nematodes and plant diseases. J. Invertebr. Pathol. 2008, 98, 256-261. [CrossRef]

61. Kope, H.H.; Leal, I. A new species of Lecanicillium isolated from the white pine weevil. Mycotaxon 2005, 94, 331-340.

62. Chiriví-Salomón, J.S.; Danies, G.; Restrepo, S.; Sanjuan, T. Lecanicillium sabanense sp. nov. (Cordycipitaceae) a new fungal entomopathogen of coccids. Phytotaxa 2015, 234, 63-74.

63. Kepler, R.M.; Luangsa-ard, J.J.; Hywel-Jones, N.L.; Quandt, C.A.; Sung, G.H.; Rehner, S.A.; Aime, M.C.; Henkel, T.W.; Sanjuan, T.; Zare, R.; et al. A phylogenetically-based nomenclature for Cordycipitaceae (Hypocreales). IMA Fungus 2017, 8, 335-353. [CrossRef]

64. Wang, W.J.; Li, Y.; Wang, X.L.; Kirk, P.M.; Yao, Y.J. Neotypification of Paecilomyces hepiali (Hypocreales). Taxon 2015, 64, 147-150. [CrossRef]

65. Dai, R.Q.; Shen, C.Y.; Li, X.M.; Lan, J.L.; Lin, S.F.; Shao, A.J. Response to neotypification of Paecilomyces hepiali (Hypocreales) (Wang et al. 2015). Taxon 2018, 67, 784-786. [CrossRef]

66. Samson, R.A. Paecilomyces and some allied hyphomycetes. Stud. Mycol. 1974, 6, 1-119.

67. Mongkolsamrit, S.; Noisripoom, W.; Thanakitpipattana, D.; Wutikhun, T.; Spatafora, J.W.; Luangsa-ard, J. Disentangling cryptic species with Isaria-like morphs in Cordycipitaceae. Mycologia 2018, 110, $230-257$. [CrossRef]

(C) 2020 by the authors. Licensee MDPI, Basel, Switzerland. This article is an open access article distributed under the terms and conditions of the Creative Commons Attribution (CC BY) license (http://creativecommons.org/licenses/by/4.0/). 